\title{
Vodní měkkýši přehradní nádrže Slapy (Česká republika) Aquatic molluscs of the Slapy Reservoir (Czech Republic)
}

\author{
LUBOŠ BERAN \\ Správa Chráněné krajinné oblasti Kokořinsko, Česká 149, CZ-27601 Mělník, e-mail: lubos.beran@nature.cz
}

\begin{abstract}
BERAN L., 2007: Vodní měkkýši přehradní nádrže Slapy (Česká republika) [Aquatic molluscs of the Slapy Reservoir (Czech Republic)]. - Malacologica Bohemoslovaca, 6: 11-16. Online serial at $<$ http://mollusca.sav.sk> 15-March-2007.

This paper brings a review of a malacological survey of the Slapy Reservoir (Central Bohemia, Czech Republic). This dam water reservoir was built in 1957 on the Vltava River with area 1392 ha, length $44 \mathrm{~km}$, max. deepness $58 \mathrm{~m}$ and altitude $270.6 \mathrm{~m}$. Aquatic molluscs at 22 sites were studied from 2005 to 2006 . Altogether, 30 species of aquatic molluscs (21 gastropods, 9 bivalves) which represent nearly $40 \%$ of the total Czech aquatic mollusc fauna were found despite the absence of littoral vegetation. Bithynia tentaculata, Radix auricularia, R. cf. ampla, Gyraulus albus, Hippeutis complanatus, Sphaerium corneum, Anodonta anatina and surprisingly also vulnerable Anodonta cygnea belong to most frequent molluscs found during this research. Record of near threatened gastropod Viviparus viviparus fill in long gap among its occurrence in the Vltava River downstream of the Slapy Reservoir (last of the dam water reservoirs on the Vltava River) and in tributaries of the Vltava River in Southern Bohemia (Lužnice, Nežárka). Occurrence of four non-native species (Potamopyrgus antipodarum, Physella acuta, Menetus dilatatus, Ferrissia fragilis) were documented.
\end{abstract}

Key words: Aquatic molluscs, impounding reservoir, Vltava River, human impact.

\section{Úvod}

Přehradní nádrže byly stanovištěm českými malakology dlouho opomíjeným, a to i přes jejich relativně značný počet. Po průzkumu naší největší vodní nádrže Lipno, který přinesl překvapivé výsledky (DVOŘÁK \& BERAN 2004, BERAN 2005a, BERAN \& DVOŘÁK 2006) byla pozornost věnována i vodní (přehradní) nádrži Slapy.

\section{Metodika a materiál}

Historická data byla získána $\mathrm{z}$ autorovy databáze, která obsahuje přepis dostupných publikovaných i nepublikovaných prací, údaje získané z kartoték a sbírek muzeí a od jiných malakologů. Údaje o současném rozšíření použité $\mathrm{v}$ této práci jsou získané vlastním terénním průzkumem autora. Průzkum byl proveden na 22 lokalitách na území vodní nádrže Slapy v roce 2005 a 2006 a to v době, kdy hladina vody v nádrži byla $v$ rozmezí cca $267-268 \mathrm{~m}$ n.m., tzn. cca 2,5-3,5 m pod svou maximální provozní hladinou (270,6 m n.m.). Pozornost byla věnována zejména různě rozlehlým zátokám, které slibovaly vhodnější prostředí pro rozvoj společenstev vodních měkkýšů. Sběr byl na většině lokalit prováděn kombinací vizuální metody a odběrů sedimentu za pomoci kovového kuchyňského cedníku (průměr $20 \mathrm{~cm}$, velikost ok 0,5-1 mm).

Materiál, získaný při průzkumu, byl ve většině případů určen na místě a vrácen na lokalitu. V prrípadě vzácných druhů (v tomto př́ípadě Menetus dilatatus) byla alespoň část sběru uložena do sbírky autora. U druhů determinovatelných pouze pomocí lupy (např. většina druhů rodu Pisidium) byl materiál determinován až v laboratoři. Žádní jedinci nebyli determinováni pomocí pitvy, resp. s výjimkou rodu Radix to nebylo zapotřebí (viz poznámka 
k rodu Radix). Systém a nomenklatura jsou prévzaty z práce BERAN (2002) a upraveny podle aktuální verze přehledu měkkýšů ČR (JUŘIČKOVÁ et al. 2007).

\section{Charakteristika území}

Vodní nádrž Slapy na řece Vltavě leží 18 km západně od Benešova a její stavba byla dokončena v roce 1957. Rozloha vodní plochy činí 1392 ha, maximální hloubka je $58 \mathrm{~m}$. Délka vzdutí je $44 \mathrm{~km}$ a nadmořská výška při normální hladině 270,6 m (VLČEK 1984). Břehy vodní nádrže jsou na řadě míst skalnaté, místy kamenité až písčitobahnité. $\mathrm{V}$ zátokách a to zejména $\mathrm{v}$ místech, kde ústí drobné přítoky, jsou časté bahnité a písčitobahnité sedimenty. Porosty vodní a mokřadní vegetace jsou velmi sporé.

\section{Přehled lokalit}

V této části jsou uvedeny popisy jednotlivých lokalit. Údaje jsou řazeny následovně: číslo lokality, zeměpisné souřadnice, název nejbližší obce, kód pole pro faunistické mapování (BUCHAR 1982, PRUNER \& MíKA 1996), lokalizace a popis lokality, datum průzkumu. Lokality jsou řazeny zhruba ve směru od severu $\mathrm{k}$ jihu.

1 - 494' $58^{\prime \prime}$ N, 14²5'12" E, Slapy, 6152, břehy vodní nádrže Slapy a zátoky východně od Slap, $13.11 .2005 ; \quad 2$ - 4947'54"-49 48'03" N, $14^{\circ} 25^{\prime} 06^{\prime \prime}-14^{\circ} 25^{\prime} 34^{\prime \prime}$ E, Ždáň, 6152, břehy zátoky vodní nádrže Slapy u Ždáně, 13.11.2005; 3 4947'56" N, 14²6'29" E, Měřín, 6252, Punčochářská zátoka vodní nádrže Slapy severovýchodně od obce Měŕín, 20.11.2006; 4 - 4946'92" N, 14²5'38" E, Jablonná, 6252, Jablonecká zátoka vodní nádrže Slapy západně od Jablonné, 20.11.2006; 5 - 4946'76" N, 14²4'18" E, Čím, 6252, Č́mská zátoka vodní nádrže Slapy východně od obce Čím, 20.11.2006; 6 - 4945'74" N, 142ㄴ'06" E, Živohošt', 6252, malá zátoka vodní nádrže Slapy na severozápadním okraji Živohoště, 20.11.2006; 7 - 4945'16" N, 14²5'13" E, Nahoruby, 6252, malá zátoka vodní nádrže Slapy východně od Nové Živohoště, 20.11.2006; 8 4944'93" N, 14²4'83" E, Nahoruby, 6252, zátoka Mastník u Nové Živohoště asi 300 m před vodní nádrží Slapy, 20.11.2006; 9 - 4944'00" N, 14²4'66" E, Poličany, 6252, zátoka Mastník u ústí drobného př́toku západojihozápadně od Poličan, 20.11.2006; 10 - 4943'90" N, 14²5'40" E, Poličany, 6252, zátoka Mastník asi 500 m od ústí potoka Mastník jižně od Poličan, 20.11.2006; 11 4943'51" N, 14²5'52" E, Poličany, 6252, zátoka Mastník u Kasáren u ústí potoka Mastník jihovýchodně od Poličan (rozsáhlé porosty orobince), 24.11.2006; 12 - 4943'24"-49 44'13" N,

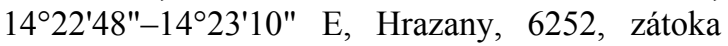
vodní nádrže Slapy u ústí potoka Musík východně od Přední Hluboké, 19.11.2005; 13 - 4943'45" N,
14²1'17" E, Smilovice, 6252, západní část Žraločí zátoky vodní nádrže Slapy u ústí Čelinského potoka, 19.11.2006; $14-49^{\circ} 43^{\prime} 23^{\prime \prime} \mathrm{N}, 1^{\circ} 21^{\prime} 07^{\prime \prime} \mathrm{E}$ a 4943'17" N, 14²1'15" E, Křepenice, 6252, dvě malé zátoky vodní nádrže Slapy v osadě Oboz severně od Křepenic, 19.11.2005; 15 - 4943'01" N, 14²19'32" E, Cholín, 6251, pravý břeh vodní nádrže Slapy u mostu v Cholíně (na protější straně než je Cholín), 26.11.2006; 16 - 4943'30" N, 14¹8'38" E, Hubenov, 6251, Hubenovská zátoka vodní nádrže Slapy východně od Hubenova, 19.11.2006; 17 - 4942'09" N, 14¹8'49" E, Zvírotice, 6251, malá zátoka vodní nádrže Slapy pod chatovou osadou asi $1 \mathrm{~km}$ východně od Zvírotic, 26.11.2006; 18 - 49 $42^{\prime} 21^{\prime \prime} \mathrm{N}, 1^{\circ} 17^{\prime} 57^{\prime \prime}$ E, 6251, Županovice, břeh vodní nádrže Slapy u ústí malého potůčku v Županovicích, 19.11.2006; 19 4941'47" N, 14¹7'52" E, Zvírotice, 6351, břeh vodní nádrže Slapy na jihozápadním okraji Zvírotic, 26.11.2006; 20 - 4940'35" N, 14¹7'23" E, 6351, Zrůbek, zátoka vodní nádrže Slapy v okolí silničního mostu (na obě strany - zátoka i vlastní nádrž) u Zrůbku, 24.11.2006; 21 - 4940'19" N, 14¹7'35" E, 6351, Zrůbek, zátoka vodní nádrže Slapy u ústí potoka Brzina, 24.11.2006; 22 49³9'41" N, 14¹5'09" E, 6351, Velká, břeh vodní nádrže Slapy v obci Velká u ústí Vápenického potoka, 24.11.2006.

\section{Dosavadní malakologické průzkumy}

Je s podivem, že z celého dnešního území vodní nádrže Slapy (tzn. i z Vltavy před její stavbou) se podařilo nalézt prakticky jediné historické údaje o vodní malakofauně. Jedná se o údaje Vojena Ložka, který nalezl 31.10.1984 3 druhy (Bithynia tentaculata, Radix ampla, Bathyomphalus contortus) ve vodní nádrži Slapy u Cholína. Na stejném místě nalezl opět 3 druhy (Bithynia tentaculata, Radix ampla, Gyraulus albus) při zběžném průzkumu L. Beran 20.7.1998.

\section{Výsledky}

V této části jsou uvedeny výsledky průzkumu podle jednotlivých druhů. U každého druhu je uveden kromě vědeckého názvu i český ekvivalent a zoogeografické rozšíření převzaté z práce BERAN (2002). Jsou zde uvedeny také údaje týkající se obývaných stanovišt', poznámky k rozšíření na území ČR a rozšíření ve sledované oblasti.

\section{Třída: Gastropoda}

Řád: Architaenioglossa

Čeled': Viviparidae

Viviparus viviparus (Linnaeus, 1758) - bahenka pruhovaná. Evropský druh. Typický plž větších a úživnějších vodních toků. V minulosti druh omezený pouze na největší české řeky (Labe, Vltava), který s rostoucím zatížením živinami přesunul svůj výskyt i do menších řek. Výskyt ve vodní nádrži 
Slapy je zřejmě nejpřekvapivějším nálezem, nebot' tento vzácnější druh z oblasti Vltavské kaskády není znám a také se obvykle vyskytuje pouze $\mathrm{v}$ tekoucích vodách. Zjištěn byl na třech lokalitách ležících blízko sebe mezi Cholínem a Županovicemi. Tento výskyt tak alespoň částečně vyplňuje rozsáhlou mezeru $\mathrm{v}$ rozšíření tohoto druhu mezi relativně souvislým výskytem pod vodní nádrží Slapy a izolovanou oblastí v okolí ústí Nežárky do Lužnice v jižních Čechách.

Řád: Neotaenioglossa

Čeled': Hydrobiidae

Potamopyrgus antipodarum (Gray, 1843) - písečník novozélandský. Druh zavlečený do Evropy z Nového Zélandu. V současnosti běžný a šiřící se druh zejména v Polabí a severozápadních Čechách. Obývá především pískovny, odstavená ramena a vodní toky se štěrkopísčitými sedimenty. Zoologicky významný nález, který je nejjižnějším nálezem v Čechách a zároveň nejvýše položeným proti proudu Vltavy. Opět zjištěn na třech místech.

\section{Čeled': Bithyniidae}

Bithynia tentaculata (Linnaeus, 1758) - bahnivka rmutná. Palearktický druh. Běžný druh pomaleji tekoucích a úživnějších vodních toků a nepř́liš zazemněných a zarostlých stojatých vod. Patří k nejpočetnějším a nejčastěji nalezeným plžům vodní nádrže Slapy a byl zjištěn na všech 22 zkoumaných lokalitách.

Řád: Ectobranchia

Čeled': Valvatidae

Valvata cristata O.F. Müller, 1774 - točenka plochá. Palearktický druh. Běžný druh mělkých a zarostlých stojatých vod. Jeho občasný výskyt (6 lokalit) ve vodní nádrži Slapy, která je velmi chudá na vodní vegetaci, je relativně překvapivý.

Valvata piscinalis (O.F. Müller, 1774) - točenka kulovitá. Palearktický druh. V současnosti již nepřiliš běžný druh obývající především pomaleji tekoucí úživnější vodní toky. Ve vodní nádrži Slapy patři k pravidelným druhům vyskytujícím se na bahnitopísčitých sedimentech.

Rád: Hygrophila

Čeled': Acroloxidae

Acroloxus lacustris (Linnaeus, 1758) - člunice jezerní. Palearktický druh. Běžný obyvatel především větších stojatých př́padně pomaleji tekoucích vod. Je zajímavé, že tento druh byl zjištěn pouze na 3 lokalitách.

Čeled': Lymnaeidae

Galba truncatula (O.F. Müller, 1774) - bahnatka malá. Holarktický druh. Běžný druh, který se obvykle vyskytuje na rozhraní mezi vodou a souší (břehy vodních toků, mokřady). Kolísající hladina vodní nádrže a absence vhodných biotopů je však př́činou malého zastoupení (4 lokality).

Radix auricularia (Linnaeus, 1758) - uchatka nadmutá. Palearktický druh. Obývá velké spektrum biotopů kromě prŕliš zarostlých a zazemněných stojatých vod. Je typickým pionýrským druhem obnovených či nově vytvořených biotopů (pískovny). Běžný je i výskyt $\mathrm{v}$ pomaleji tekoucích vodách. Ve vodní nádrži Slapy patři k nejčastěji (19 míst) zastiženým druhům.

Radix cf. ampla (Hartmann, 1821) - uchatka široká. Palearktický druh. Plž charakteristický pro větší vodní toky. Stejně jako předchozí druh patří k nejčastěji (20 lokalit) zastiženým druhům. Taxonomie rodu Radix není prozatím spolehlivě dořešena a i př́slušnost nalezených jedinců k druhu $R$. ampla není jistá.

Radix cf. peregra (O.F. Müller, 1774) - uchatka toulavá. Palearktický druh. Typický druh méně úživných vodních toků, nádrží a mokřadů. Ve sledovaném území zjištěn na třech lokalitách. Blíže viz poznámka $\mathrm{k}$ předchozímu druhu.

Lymnaea stagnalis (Linnaeus, 1758) - plovatka bahenní. Holarktický druh. Běžný druh stojatých a pomalu tekoucích vod. Ve vodní nádrži Slapy byl však zjištěn pouze na jediné lokalitě, kde se vyskytují bohatší litorální porosty.

\section{Čeled': Physidae}

Physa fontinalis (Linnaeus, 1758) - levatka říční. Holarktický druh. V současnosti již vzácnější obyvatel odstavených ramen a tůní a pomaleji tekoucích vodních toků, který preferuje bohatěji zarostlé biotopy. $\mathrm{Z}$ tohoto důvodu byl zjištěn pouze na 2 lokalitách.

Physella acuta (Draparnaud, 1805) - levatka ostrá. Druh zavlečený ze Severní Ameriky (cf. např. BERAN 2005b). Běžný obyvatel vodních toků (i silně znečistěných) a především druhotných či upravených stojatých vod (např. pískovny, nově vytvářené tůně a rybníky). Jeho výskyt ve vodní nádrži Slapy je poměrně zajímavý, nebot' byl zjištěn prakticky na všech lokalitách, ale až od lokality č. 7 výše proti proudu Vltavy.

\section{Čeled': Planorbidae}

Anisus leucostoma (Millet, 1813) - svinutec běloústý. Evropsko-západosibiřský druh. Typický obyvatel periodických tůní a mokřadů od nížin až po vyšší polohy. Ve vodní nádrži Slapy byl zjištěn pouze na jediné lokalitě (č. 11), která alespoň trochu odpovídá jeho životním nárokům.

Bathyomphalus contortus (Linnaeus, 1758) - řemeník svinutý. Palearktický druh. Druh obývá zejména zarostlé tůně a okraje rybníků, nezřídka i pomaleji tekoucí vodní toky (např. nad jezy). Výskyt na 12 zkoumaných lokalitách je poměrně překvapivý. 
Gyraulus albus (O.F. Müller, 1774) - kružník bělavý. Palearktický druh. Běžný druh na většině území ČR, který obývá široké spektrum biotopů a to zejména méně zarostlých. I z tohoto důvodu patř́ k nejpočetněji a nejčastěji zjištěným druhům, respektive byl zjištěn na všech zkoumaných lokalitách.

Gyraulus crista (Linnaeus, 1758) - ostníček žebernatý. Holarktický druh. Běžný druh trvalých stojatých vod, který byl v malém počtu zjištěn na 5 lokalitách.

Hippeutis complanatus (Linnaeus, 1758) - kýlnatec čočkovitý. Palearktický druh. Opět běžný druh především trvalých stojatých vod, který byl nalezen na 17 lokalitách, ale vždy pouze v malých počtech. Menetus dilatatus (Gould, 1841) - menetovník rozšířrený. Další nepůvodní druh zavlečený ze Severní Ameriky. Nález tohoto plže doplňuje nedávno zjištěné výskyty ve vodní nádrži Lipno (BERAN 2005a) a Orlík (BERAN 2003). Až do zmíněných nálezů byl znám především $z$ Polabí a to jak z vlastního toku Labe, tak i z řady odstavených ramen a také pískoven.

Ancylus fluviatilis O.F. Müller, 1774 - kamomil říční. Evropský druh. Druh tekoucích vod, který byl zjištěn jen na jediné lokalitě bezprostředně pod ústím drobného př́ítoku.

Ferrissia fragilis (Tryon, 1863) - člunka pravohrotá. Poslední nepůvodní druh zavlečený ze Severní Ameriky. V České republice běžnější druh především v zarostlých stojatých a pomalu tekoucích vodách v širší oblasti Polabí. Ve vodní nádrži Slapy zjištěn pouze na 3 lokalitách, ale tento výskyt doplňuje znalosti o současném výskytu a šíření druhu.

Tř́ída: Bivalvia

Řád: Unionoida

Čeled': Unionidae

Unio pictorum (Linnaeus, 1758) - velevrub malírský. Evropský druh. Nejběžnější zástupce rodu Unio v České republice, který byl nalezen pouze na jediné lokalitě a to ještě pouze $v$ několika jedincích.

Anodonta cygnea (Linnaeus, 1758) - škeble rybničná. Eurosibiřský druh. V současnosti již vzácnější druh obývající odstavená ramena, tůně a vodní nádrže. Druh je zařazen v Červeném seznamu vodních měkkýšů ČR mezi druhy zranitelné (BERAN 2002) a zároveň je v seznamu zvláště chráněných druhů živočichů uveden jako silně ohrožený druh. Ve vodní nádrži Slapy patří k častým druhům a byl zjištěn na 16 lokalitách.

Anodonta anatina (Linnaeus, 1758) - škeble říční. Eurosibiřský druh. Zřejmě nejběžnější velký mlž v rámci ČR, vyskytující se v tekoucích i větších stojatých vodách. Ve vodní nádrži Slapy patří k druhům zjištěným na všech lokalitách a to v některých př́padech i ve velmi početných populacích.

\section{Rád: Veneroida}

Čeled': Sphaeriidae

Sphaerium corneum (Linnaeus, 1758) s.lat. okružanka rohovitá. Palearktický druh (taxon). Velmi častý mlž žijící především v živinami bohatých pomaleji tekoucích vodách, který byl zjištěn na 18 zkoumaných lokalitách a patří tak mezi nejčastěji zjištěné druhy.

Musculium lacustre (O.F. Müller, 1774) - okrouhlice rybničná. Holarktický druh. V ČR mozaikovitě rozšiřrený druh, který obývá pomaleji tekoucí a stojaté vody. Při průzkumu vodní nádrže Slapy byl nalezen na 14 lokalitách.

Pisidium henslowanum (Sheppard, 1823) - hrachovka hrbolatá. Holarktický druh. Relativně běžný druh vyskytující se především $\mathrm{v}$ tekoucích vodách a odstavených ramenech řek v nižších polohách. Zjištěn byl v bahnitých a písčitobahnitých sedimentech na polovině (11) lokalit.

Pisidium subtruncatum Malm, 1855 - hrachovka otupená. Holarktický druh. Jedna z nejběžnějších hrachovek žijící především ve vodních tocích, ale také v řadě typů stojatých vod. Zjištěna byla na 7 lokalitách.

Pisidium nitidum Jenyns, 1832 - hrachovka lesklá. Holarktický druh. Opět poměrně běžný druh nalezený na 16 lokalitách.

Pisidium casertanum (Poli, 1791) - hrachovka obecná. Pravděpodobně kosmopolitní druh. Zřejmě nejběžnější hrachovka rodu Pisidium v ČR, která se vyskytuje $\mathrm{v}$ řadě vodních stanovišt' od pramenišst' a mokřadů až po velké vodní toky. Ve zkoumaném území zjištěna na dvou místech. 


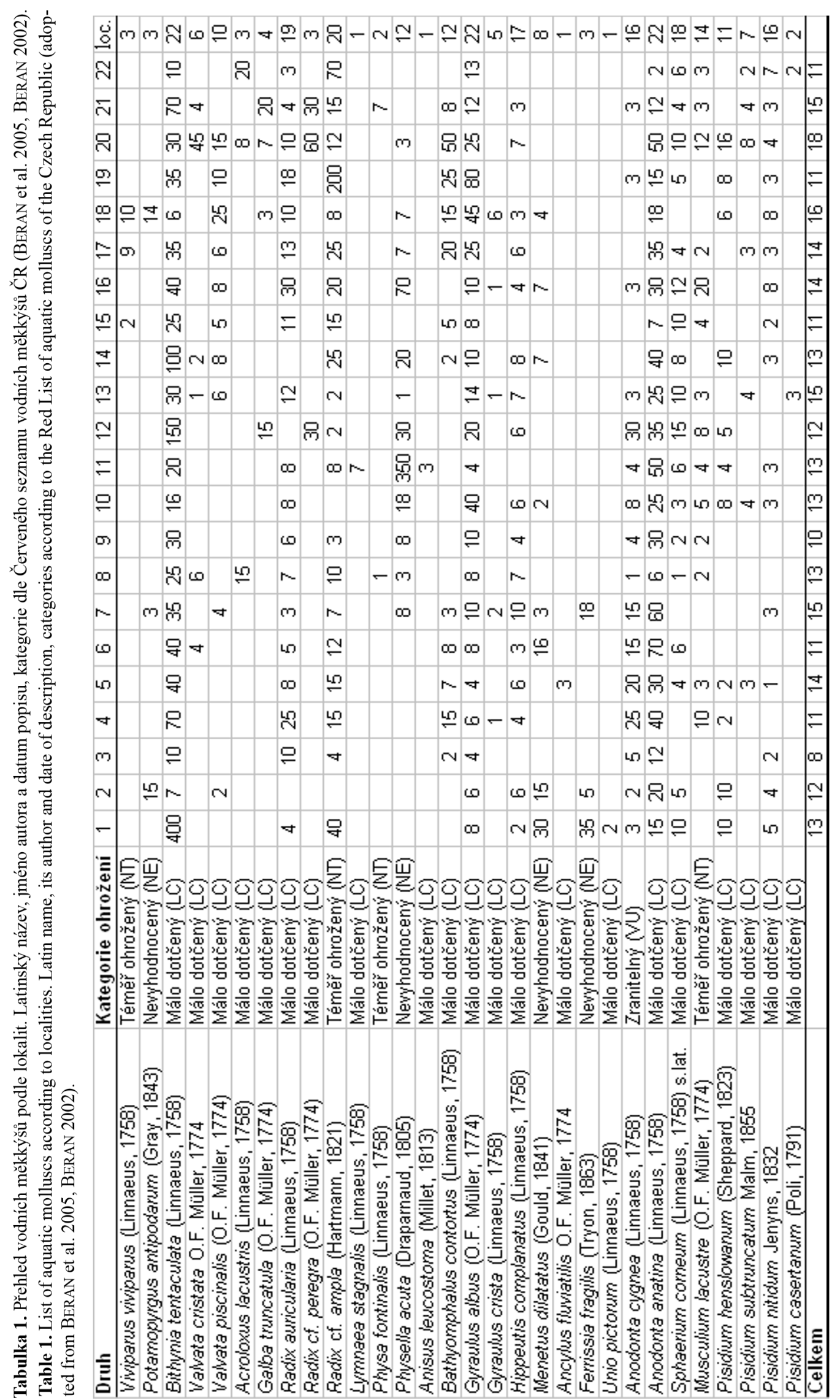




\section{Diskuse a závěr}

Malakozoologický průzkum vodní nádrže Slapy v letech 2005 a 2006 doložil výskyt 30 druhů vodních měkkýšů (21 plžů, 9 mlžů), což je téměř $40 \%$ druhového bohatství našich vodních měkkýšů. Vzhledem k relativní uniformitě vodních stanovišst', $\mathrm{k}$ absenci vodní a mokřadní vegetace na většině lokalit a také ke změnám výšky vodní hladiny je tento počet velmi prŕjemným překvapením. Porovnání se nabízí zejména s nedávno zkoumanou vodní nádrží Lipno (DVOŘÁK \& BERAN 2004, BERAN \& DVOŘÁK 2006), kde bylo zjištěno 25 druhů. Vodní nádrž Lipno leží však ve výrazně větší nadmořské výšce $(725 \mathrm{~m})$, ale na druhou stranu jsou zde rozvinuty bohaté porosty litorální vegetace. Nejčastější a nejpočetnější složkou malakocenóz vodní nádrže Slapy jsou poměrně běžné druhy jako Bithynia tentaculata, Radix auricularia, $R$. cf. ampla, Gyraulus albus, Hippeutis complanatus, Sphaerium corneum, Anodonta anatina a překvapivě také mnohem vzácnější a zranitelná (BERAN et al. 2005) Anodonta cygnea. S výjimkou druhů Hippeutis complanatus a Anodonta cygnea se zároveň jednalo i o nejčastější a nejpočetnější druhy podél vlastního břehu vodní nádrže, zatímco zátoky oplývaly bohatšími společenstvy vodních měkkýšů. Dalších 10 druhů, které byly zjištěny na nejméně 5 lokalitách je relativně pravidelnou i když početně mnohem méně zastoupenou součástí malakocenóz. Zajímavý je výskyt zavlečené levatky Physella acuta. Ta se vyskytuje téměř na všech lokalitách po proudu níže od Živohoště, zatímco výše proti proudu zjištěna nebyla vůbec. Zbylé druhy byly nalezeny pouze na jedné či několika málo lokalitách. Zoologicky významné jsou nálezy zavlečených druhů. Zmíněna již byla původně severoamerická Physella acuta. Dále byl zjištěn Potamopyrgus antipodarum zavlečený do Evropy z Nového Zélandu a opět severoamerické druhy Menetus dilatatus a Ferrissia clessiniana. $\mathrm{V}$ př́ípadě všech 4 druhů se jedná o jejich první nálezy v širší oblasti vodní nádrže Slapy a okolí. V př́padě písečníka Potamopyrgus antipodarum se jedná o nejjižnější výskyt v Čechách a nález menetovníka Menetus dilatatus doplňuje doposud známé výskyty ve vodní nádrži Lipno (BERAN 2005a) a Orlík (BERAN 2003). Největším překvapením však byl nález bahenky Viviparus viviparus. V rámci Čech se jedná o první nález tohoto ,کríčního“ druhu v přehradní nádrži a zároveň první nález z oblasti Vltavské kaskády. Celkově přinesl průzkum malakofauny vodní nádrže Slapy řadu velmi zajímavých výsledků, které významně posunuly naše znalosti o vodních malakocenózách našich přehradních vodních nádrží.
Poděkování. Povodí Vltavy, s.p. děkuji především za technickou pomoc.

\section{Literatura}

BERAN L., 2002: Vodní měkkýši České republiky - rozšíření a jeho změny, stanoviště, šíření, ohrožení a ochrana, červený seznam [Aquatic molluscs of the Czech Republic - distribution and its changes, habitats, dispersal, threat and protection, Red List]. Sborník př́rodovědného klubu v Uh. Hradišti, Supplementum 10, $258 \mathrm{pp}$.

BERAN L., 2003: Nález severoamerického druhu Menetus dilatatus (Mollusca: Gastropoda) v jižních Čechách (Česká republika) [Record of Menetus dilatatus (Mollusca: Gastropoda) in the Southern Bohemia (Czech Republic)]. - Malacologica Bohemoslovaca (Československá slimač), 2: 1-2.

BERAN L., 2005a: Menetus dilatatus (Gould, 1841) (Gastropoda: Planorbidae) in the Lipno Reservoir (Southern Bohemia, Czech Republic). - Malacologica Bohemoslovaca, 4: 17-20.

BERAN L., 2005b: Which Physella (Mollusca: Gastropoda) lives in the Czech Republic? - Acta Soc. Zool. Bohem., 68: 241-243.

BERAN L., JUŘičKOVÁ L. \& HoRSÁK M. 2005: Mollusca (měkkýši), pp. 69-74. - In: Červený seznam ohrožených druhů České republiky. Bezobratlí. Red list of threatened species in the Czech Republic. Invertebrates, FARKAČ J., KRÁL D. \& ŠKORPÍK M. (eds) Agentura ochrany př́rody a krajiny ČR, Praha, 760 pp.

BERAN L. \& DVOŘÁK L., 2006: New records of aquatic molluses in the Lipno Reservoir and its surroundings II. - Silva Gabreta, 12: 133-142.

BUCHAR J., 1982: Způsob publikace lokalit živočichů z území Československa. - Věst. Čs. Společ. Zool., 46: 317-318.

DVOŘÁK L. \& BERAN L., 2004: Remarkable records of aquatic molluscs in the Lipno Reservoir and its environs. - Silva Gabreta, 10: 97-106.

JuŘIČKovÁ L., HorsÁK M., BERAN L. \& DvořÁK L. 2007: Check-list of the molluscs (Mollusca) of the Czech Republic. - http://www.mollusca.sav.sk/ malacology/checklist.htm.

PRUNER L. \& MíkA P., 1996. Seznam obcí a jejich částí v České republice s čísly mapových polí pro sítové mapování fauny [List of settlements in the Czech Republic with associated map field codes for faunistic grid mapping system]. - Klapalekiana, 32, Suppl.: $1-175$.

VLČEK V. (ed.), 1984: Vodní toky a nádrže. Zeměpisný lexikon ČSR. Academia, Praha, 316 pp. 